\title{
掘進における諸問 題
}

[II] 後方運搬

座長大隅 芳 雄*

18日 9 時より開会, 昨日に引続き出席者も 200 名をは るかに越える盛会であつた。

掘進成績を上げるためには, 後方運搬をいかに能率化 するかは，すこぶる重要な問題であり，その適否が，掘 進工程上昇の鍵となることは，いうまでもないことであ る。

本日の議題は, 広義に解釈し, 小運搬一中間運搬一後 方運搬と, 切羽におけるズリ処理, 積込から坑口に運び 出すまでの全体を含めて研究討議を願うこととした。

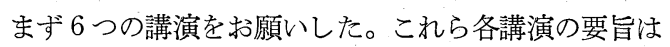
後に掲げるが, それらの要点と各講演に対する質疑の主 なものを縓めると次のとおりである。

(1) 三井建設 植木の講演は, 切羽における菡操作 について討議するため, 一例として三井三池におけるエ ヤーブロックとワイヤロープによる吊上げ方式の簡易操 車機について紹介を願つたものである。

（2）山陽無煙 高山は傾斜 $20^{\circ}$ の昇掘進の積込みに 対し種々検討の結果，スクレーパー，スラッシャを使用 し，従来のベビーコンベヤ使用による手積に比較して約 20\%の能率向上を得た実績について述べられ, 緩傾斜昇 掘進における積込法に対する参考資料を提供された。

問 スクレーパー ロープの摩耗状態はどうか。

答 ロープの素線のいたみ大。 $200 \mathrm{~m} /$ 月 程度使用。

問 スクレーパー積込みと人力積込みの比率。

答 大部分スクレーパー積込み。スクレーパーで積めな いものや，側壁付近のものを中央に搔き出すのに人力を 使用する程度。

（3）太空機械 高橋は三井金属神岡鉱業所で開発さ れたものをもとに，同社で改良，実用化したセルフスタ ンド・コンベヤローダについてその特長, 型式の種類, 運転操作などについて述べられ，ついで(4)小松氏（松 永氏代理）は本機開発に至るまでのいきさつ，1号機よ り 3 号機完成に至るまでの経過, ならびに順次掘進成績 を向上して，ついに 3 号機使用により月延 $420.1 \mathrm{~m}$ の記 録を達成した実績について述べられた。

なおセルフスタンディング・コンベヤローダについて

* 工博 九州大学教授 工学部採鈗学科
は炭鉱における卸掘進に使用した例として，三菱古賀山 鉱業所の実績紹介を予定していたが，同所水害のため, 発表取り止めとなつたことは残念であつた。

（5）南大夕張 吉田は同所の大断面斜坑掘進におい て，サイドダンプローダとモノレール式コンベヤの組み 合わせによる列車積方式を採用した掘進実績について述 ベられた。

問 コンベヤの積込口の傾斜 $28^{\circ}$ でズリ積みは可能か。

答 ダブルチェーン・スクレーパー・コンベヤであるか ら可能である。

（6）三井建設 石崎は太平洋炭砿の卸掘進工事にお いてギャザリングローダとバンカートレーンの組み合わ せにより新記録を樹立した実績について，バンカートレ ーン採用の理由およびその設計上の要点, 急速掘進実施 上の問題点の克服と将来への指針などについて述べられ た。

以上で予定の講演を終了し, 11時 5 分よりまず講演に 対する質疑に入つた。その主なものはすでに揭げたとお りである。ついで本日の議題ならびに昨日の穿孔長, サ イクル数の問題も含めて討議に移つた。その主なものは 次のとおりである。

座長 掘進切羽における函操作については, どこでも関 心の高い問題と思われるが，ほかに，よい方法をとつて おられるところはないか。北海道の炭鉱では，どんな方 法を採用しておられるか。

宮（三井釷山） 三井砂川ではコロ付き転車台とカーシフ ター，三井芦別では分岐板による方法をとつている。

座長 ズリの粒度と飛散距離は積込みに重要な関係があ り，また倒枠の問題もある。積込機と粒度の関係，およ び適当な粒度と飛散距離を得るための発破法，火薬量な ぞについて意見を伺いたい。日鉄有明ではそれについて 実験されたと伺つているが，その結果を説明願いたい。 竹中 (日鉄有明) 従来D.Sを使用してきたが，大塊が多 過ぎ，また残ダイが多過ぎの 2 点の弊害があるので， D.S M.S に変えた。その結果，上の 2 点については ある程度解決したが，一方において飛散距離が大きい, 倒枠の発生が多いの 2 点の障害が出た。そこで発破規格 
を種々変えて実験した結果，現在ではできるだけ心抜の 位置を低くとる発破法を採用している。

座長 昨日の問題と関連してVカット, バーンカット， ラインカットなど発破法についてご討議願いたい。

御厨 (三井建設) ラインカットは失敗が多い。3 4 回に 1 回は失敗がある。ほとんどのところで $\mathrm{V}$ カッを採用 しているのは，そのためと思われる。三川の坂田さんに 成功の秘訣を伺いたい。

あいにく坂田氏不在のため伺えなかつたのは残念であ つた。

鳥田 (九技連) 四山鉣では岩石掘進においても相当の実 績をあげているが，三川鉱と四山鉱の掘進方法の比較に ついて野村さんに説明願いたい。

野村 (三池四山) 現場の掘進担当技術者としては, $500 \mathrm{~m} /$ 月が目標である。四山の硬質砂岩に対しVカットではこ れまであげた実績の $387.2 \mathrm{~m} /$ 月 が限度である。Vカッ トでは 1 発破の起砕は $1.21 \mathrm{~m}$ が限度で $1.3 \mathrm{~m}$ は無理であ る。三川鉱でも同様の理由からラインカット方式を採用 することにより $423.7 \mathrm{~m} /$ 月の記録を達成したのである。

つぎに $500 \mathrm{~m} /$ 月 を達成するためには，つぎのことが 必要と考える。

1) 4 サイクル/方

2）ワンカットで 1.7 2.0m を起砕しうる発破法の 研究

3）切羽の集積ズリを迅速に処理すること。機械化に より少なくとも 30 分程度で 1 発破分を処理する。そのた
めには RS-75 を2 台使用するか，またはギャザリング ・ローダ $\left(150 \sim 200 \mathrm{~m}^{3} / \mathrm{h}\right)$ を使用する。それには $\mathrm{V} カ ッ$ トではズリが飛散するから不利である。

4）穿孔速度を増大する。少なくとも $80 \sim 100 \mathrm{~cm} / \mathrm{min}$ の速度が必要である。現在 TY-24 では 40 50 cm $/ \mathrm{min}$ 程度であるから高性能の新型さく岩機を採用する。

5）中間コンベヤを組み合わせ，ローダの性能をあげ る。

小松 (神岡) バーンカットとラインカットを組み合わせ $2.4 \mathrm{~m}$ の穿孔とし，ギャザリング・ローダを使用すれば, $400 \sim 500 \mathrm{~m} /$ 月 は可能である。

穿孔速度については, 神岡では空気圧力 $8.5 \mathrm{~kg} / \mathrm{cm}^{2}$, ビットゲージ $27 \mathrm{~mm}$ で $1.5 \mathrm{~m} / \mathrm{min}$ をあげている。ガン トリージャンボーを使用することにより掘進能率は高め られる。

座長 まだいろいろご討議願いたい問題む数々あります が，予定時間も経過したので，これで討議を終わりたい と思います。2 日間にわたり各講演者の方々には，それ ぞれ現場で得られたすぐれた実績について，短時間に要 領よく緾めてお話しいただき，非常に参考になりました ことを深く感謝いたします。またご出席の会員各位も昨 日に引続き長時間にわたり熱心にご㯖講, ご討議いただ きまして誠に有難うございました。昨日から本日にかけ てのご講演ならびにご討議の成果は, 今後の掘進技術の 向上に役立つものと信じます。

以上で討議を終了し 12 時10分, 盛会裡に閉会した。 